\title{
PKM KATEKESE TENTANG MENGHAYATI NILAI KERAJAAN ALLAH DALAM ERA DIGITAL BAGI ANGGOTA KMK. ST. MARTINUS PAROKI PERSIAPAN ST. MARINUS PU'URERE
}

\author{
Aurelius Fredimento ${ }^{1 *}$, John M. Balan² \\ 1 Universitas Flores, Ende, Indonesia \\ *Penulis Koresponsensi, email: betlehemk@gmail.com
}

Article History

Received:03/11/2020

Revised:7/11/2020

Accepted:15/11/2020

\begin{abstract}
The development and the progress of media communication at the present is a fact of the knowledge and the technology development that must be accepted. It presence like the flowing water which has a fast current that brings also two influences both positive and negative that must be accounted for the members of the Catholic Students Community Of St. Martinus Ende (KMK St. Martinus Ende). Both positive and negative influences the media community like a kinetic energy or a power attraction that attract them in a tiring ambiquity. Let them walk alone without escort of a decisive compass where they should have a rightist attitude and responsible. On the point, the guidance and assistance of the church is an offering if the church will be born a generation of the future of the church that is mature and has a certain quality based on the growth and the development of acuteness and inner to determine the attitude to the development of media communication. The process of sharpening of mind and the sharpeness of the participants can be realized by giving some activities such as: awareness, deepening and even the sharpeness of the actor of media communication as an alternative of reporting work of the God Kingdom for human beings. It becomes the main moving spirit or activator for the board of KMK Of St. Martinus Ende to plan and boring about the activity of catechism. The activity rise the method of Amos. By this method, the participants are invited to build a deeply reflection that based on thein real experiences about the media communication, while keep on self opening to the God planning will come to them and give them via the commandment of God. The commandment of God come to light, inspiration, motivate, power and critics to the participants about the using of the media communication as a media of the commandment of the kingdom of God to the world that is more progress and development lately.
\end{abstract}

Keywords: Method of Amos, Media of Communication, Value of The God Kingdom

\begin{abstract}
Abstrak. Perkembangan dan kemajuan media komunikasi saat ini merupakan sebuah fakta perkembangan Ilmu Pengetahuan dan Teknologi yang harus diterima. Kehadirannya bagaikan aliran air deras yang membawa serta dua pengaruh baik positip maupun negatip yang harus disikapi oleh anggota KMK St. Martinus secara bertanggung jawab berdasarkan ketajaman budi dan hati nuraninya. Pengaruh positip dan negatip media komunikasi ini bagaikan sebuah daya tarik magnetik yang menarik mereka pada sebuah titik ambiguitas yang melelahkan. Membiarkan mereka berjalan dalam titik ambiguitas yang berkepanjangan berarti sedang membiarkan mereka berlayar sendirian tanpa panduan kompas penentu ke arah mana seharusnya mereka bersikap secara benar dan bertanggung jawab. Pada titik ini, tuntunan dan dampingan dari Gereja merupakan tawaran yang niscahya jikalau menghendaki terlahirnya sebuah generasi masa depan Gereja yang matang dan berkualitas yang dicirikan dengan tumbuh dan berkembangnya ketajaman budi dan nurani untuk menentukan bagaimana seharusnya bersikap terhadap perkembangan media komunikasi. Proses penajaman budi dan nurani peserta ini, terealisasi dalam kegiatan penyadaran, pendalaman dan bahkan penajaman tentang peran media komunikasi sebagai media alternatif karya pewartaan Kerajaan Allah bagi manusia. Hal inilah yang sebenarnya menjadi penggerak utama bagi Para Pengurus KMK St. Martinus untuk melaksanakan kegiatan katekese ini. Melalui kegiatan katekese ini, peserta diajak untuk membangun sebuah refleksi mendalam atas pengalaman manusiawi, personal, dan sosialnya sambil terus membuka diri terhadap rencana Allah yang akan dinyatakan terhadapnya melalui Firman Allah. Metode yang diterapkan dalam kegiatan ini adalah metode amos. Melalui metode ini, peserta diajak untuk melihat realitas riil hidup mereka dan membiarkan Firman Allah meneranginya dengan tujuan untuk mengali dan menemukan akar terdalam dari aneka problem kemasyarakatan dan membiarkan Firman Allah hadir untuk menerangi dan memberikan ilham, daya dorong, kritik yang pedas dan tajam demi sebuah pengendapan kekuatan spiritual yang akan di jadikan sebagai sumber semangat dan kekuatan dalam mewartakan Kerajaan Allah.
\end{abstract}

Kata Kunci : Katekese Kontekstual, Media Komunikasi, Nilai Kerajaan Allah.

How to Cite: Fredimento, A., \& Balan, J. M. (2020). PKM KATEKESE TENTANG MENGHAYATI NILAI KERAJAAN ALLAH DALAM ERA DIGITAL BAGI ANGGOTA KMK. ST. MARTINUS PAROKI PERSIAPAN ST. MARINUS PU'URERE. Mitra Mahajana: Jurnal Pengabdian Masyarakat, 1(1), 32-41. https://doi.org/10.37478/mahajana.v1i1.716 


\section{PENDAHULUAN}

Siapapun dia saat ini tidak bisa mengelak dari arus perkembangan teknologi informasi yang menembus batas-batas pelosok desa serta menjangkau semua lapisan masyarakat. Bawaan dari kemajuan teknologi informasi adalah lahir dan berkembangnya media komunikasi yang semakin canggih. Kecanggihan media komunikasi ini, terimplementasi dalam bentuk pengkodean yang dapat di baca oleh mesin, yang sering disebut dengan media digital. Sedemikian canggihnya media digital, sehingga semua informasi dapat di buat, dilihat, distribusikan, dimodifikasi dan bisa bertahan dalam perangkat elektonik. Percepatan perkembangan media digital akhir-akhir ini turut mempengaruhi laju percepatan akses komunikasi antara manusia yang satu dengan manusia yang lainnya sambil membawa serta dua pengaruh yang pada saat yang bersamaan mengintai manusia, yakni pengaruh positip dan pengaruh negatip.

Daya pesona yang luar biasa dari media komunikasi secara positip terlihat dalam percepatan akses komunikasi dari manusia yang satu terhadap manusia yang lainnya. Sementara secara negatip, daya pesona media komunikasi hadir bagaikan bom waktu yang sedang berjalan menuju titik ledak yang menghancurkan manusia. Oleh karena itu, penggunaan media komunikasi sesungguhnya berada dalam pertimbangan budi dan hati nurani. Dalam kondisi seperti ini, Gereja harus tampil sebagai lembaga yang bertanggung jawab membentengi manusia melalui ajaran dan himbauan moral agar manusia menggunakan media komunikasi dalam kerangka kelancaran proses pewartaan Kerajaan Allah dalam semangat kasih. Ajaran serta himbauan moral Gereja harus dilaksanakan secara berkesinambungan seiring dengan percepatan perkembangan media komunikasi itu sendiri. Hal ini menjadi urgen dan mendesak demi membebaskan manusia dari ganasnya efek negatip media komunikasi yang secara perlahan-lahan mencabik keutuhan tatanan kehidupan sosial kemasyarakatan yang telah dibangun dan dijaga bersama.

Fakta-fakta kehidupan demikian secara gamblang mengakui bahwa antara perkembangan teknologi dengan konteks kehidupan sosial kemasyarakatan terdapat hubungan yang sangat erat satu terhadap yang lainnya. Dan perihal hubungan demikian, Liliweri (dalam Setiawan, 2018) menegaskan bahwa antara teknologi dengan masyarakat memiliki titik keterhubungan yang sangat signifikan. Artinya teknologi di satu sisi dapat mempengaruhi budaya manusia dan sebaliknya budaya manusia dapat mempengaruhi teknologi. Secara sosiologis, keterhubungan ini bisa dijelaskan bahwa teknologi yang merupakan salah satu aspek karya akal budi, turut juga mempengaruhi setiap aktivitas, tindakan, serta perilaku manusia. Teknologi informasi dan komunikasi mampu mengubah pola hubungan dan pola interaksi antar manusia pada umumnya. Pengaruh teknologi pada aktivitas, tindakan serta perilaku manusia memuncak pada dua pengaruh yang pada satu sisi menguntungkan manusia dan pada sisi lain mencelakakan manusia. Kedua pengaruh ini memiliki kesempatan yang sama untuk membantu dan menolong manusia sekaligus menyerang dan menghancurkan tatanan kehidupan sosial kemasyarakatan.

Dari sisi positip, media komunikasi hadir sebagai sarana untuk saling berbagi kasih dan keakraban sambil menghidupkan kembali semangat turut merasakan penderitaan sesama. Meski kehadiran mereka di pisahkan oleh jarak, mahasiswa katolik saling menjaga suasana komunikasi dengan berbagi informasi dan pengalaman hidup dalam suasana keterbukaan hati melalui media sosial. Hadirnya media komunikasi pada sisi ini justeru dapat mempertajam dan menguatkan jalinan relasi cinta dan persahabatan di antara mereka dalam keeratan dan keintiman kasih yang jujur dan melayani. Sedangkan dari sisi negatip, bahwa media komunikasi seringkali menjadi pemicu aneka persoalan dan polemik dalam kehidupan mahasiswa katolik. Rasa sosialitas di antara mereka sering terganggu dan bahkan di kalahkan oleh kehadiran media komunikasi ini. Nilai tenggang rasa, komunikasi interpersonal serta suasana canda dan tawaria yang selama ini menjadi warna khas kebangaan mahasiswa katolik, terkubur rapatrapat oleh egoiseme diri yang hanya sibuk dengan medianya. Kamar yang sebenarnya bisa menjadi tempat nyaman dalam berbagi kisah tentang dinamika kehidupan, hanya menjadi saksi 
bisu dari kesibukan masing-masing pribadi mahasiswa katolik sambil mengabaikan komunikasi dan dialog dari hati ke hati. Informasi yang mahasiswa katolik terima dari media komunikasi sering kali menyajikan pandangan yang sering tidak seimbang bahkan keliru mengenai nilai-nilai kehidupan yang di perjuangkan dan dipertahankan. Mahasiswa katolik dan kehidupannya sering dilukiskan secara kurang memadai dan seimbang oleh media. Perselingkuhan, kegiatan seks di luar perkawinan tanpa visi spiritual dan moral di gambarkan secara tidak kritis sementara dukungan positip terlalu sering diberikan pada perceraian, kontrasepsi, aborsi, homoseksualitas dan lesbianitas.

Membiarkan fenomen ini berkembang tanpa sebuah upaya prefentif dan kuratif berarti sedang menyetujui sebuah kehancuran yang siap meluluhtantahkan kelanjutan pembangunan bangsa dan Gereja di masa yang akan datang. Hal inilah yang perlu menjadi perhatian yang serius dari pelbagai pihak, karena bagaimanapun juga mahasiswa katolik adalah aset penerus perjuangan bangsa dan Gereja yang perlu dirawat dan dijaga dari keterpurukan hidup dan orientasinya. Menyelamatkan mereka bukan berarti harus membuat garis pemisah yang ekstrim antara mereka dengan media komunkasi. Menyelamatkan mereka dalam hal ini berarti membiarkan mereka terjun dan mengalami serta menikmati aneka kemajuan media komunikasi namun tetap dalam bimbingan dan penyadaran yang terus menerus bahwa media komunikasi meski secanggih apapun tetaplah sebuah sarana yang dalam penggunaannya harus di kontrol oleh pertimbangan budi dan hati nurani. Bimbingan dan penyadaran tersebut harus berorientasi pada penemuan diri serta penajaman budi dan hati nurani mahasiswa Katolik sehingga kapan dan di manapun ketika mereka berhubungan dengan media komunikasi, mereka sudah di bekali dengan kemampuan dasariah dalam memberi pertimbangan tentang efek yang positip dan efek yang negatipnya. Persamaan konsep tentang hakekat media komunikasi, harus menjadi pegangan bersama mahasiswa katolik bahwa media komunikasi dalam bentuk serta secanggih apapun hanyalah sebuah keterberian budi yang perlu disyukuri dan dimanfaatkan dalam kerangka perjuangan, penyebaran dan pewartaan nilai-nilai Kerajaan Allah. Media komunikasi untuk manusia bukan manusia untuk media komunikasi hendaknya menjadi sebuah prinsip hidup yang di genggam erat dan kuat oleh mahasiswa katolik demi kebaikan mereka di masa yang akan datang.

Penerimaan dan pemanfaatan media komunikasi untuk penyebaran dan pewartaan Kerajaan Allah sesungguhnya sudah mendapat penegasan dalam Konsili Vatikan II dalam dekrit inter mirıfica. Dalam dekrit inter mirifica artikel 2 ditegaskan bahwa Gereja secara terangterangan memberikan arahan dan penegasan kepada manusia agar di satu sisi menerima dan menikmati kemajuan Ilmu Pengetahuan dan Teknologi khususnya sarana atau media-media komunikasi modern dan di sisi lain dapat menerima dan menggunakan media komunikasi sosial sebagai media penyiaran dan pemantapan Kerajaan Allah. Penyalahgunaan media komunikasi merupakan ekspresi perlawanan terhadap Sang Pencipta Ilahi karena dapat mendatangkan kebinasaan karena salah penggunaannya. Hal inilah yang sesungguhnya menjadi titik kecemasan Gereja karena menyaksikan berbagai peristiwa yang muncul akibat kesalahan manusia dalam menggunakan media komunikasi. Penyalahgunaan sarana atau media komunikasi berakibat pudarnya penghargaan terhadap martabat pribadi manusia (Konsili Vatikan II, Dekrit Inter Mirifica, art.2).

Merujuk pada harapan dan kecemasan Gereja sebagaimana terungkap dalam dekrit ini, mahasiswa katolik diharapkan memanfaatkan media komunikasi bukan sekedar untuk mengembangkan hobi jejaringan atau untuk mendapatkan hiburan-hiburan sensasional, sampai mengesampingkan orang-orang terdekat demi yang jauh, tetapi justeru seharusnya membangun, mengembangkan dan menghidupkan nilai-nilai Kerajaan Allah dalam pelbagai konteks kehidupan yang mereka alami. Oleh karena itu, setiap pribadi mahasiswa katolik diharapkan untuk membangun kesadaran baru secara terus menerus tentang efek perbudakan media komunikasi bagi perkembangan diri dan kepribadiannya. Bagaimanapun penting dan urgennnya media komunikasi, tetaplah hanya menjadi sebuah sarana untuk suatu tujuan hidup yang lebih luhur dan mulia yakni, kemuliaan Tuhan, kebaikan sesama dan diri sendiri. 
Mahasiswa katolik yang tergabung dalam wadah Komunitas Mahasiswa Katolik St. Martinus (KMK St. Martinus) Paroki Persiapan St. Marinus Pu'urere dalam refleksi internal organisasinya menyadari sungguh tentang pengaruh negatip dari media komunikasi terhadap hidup mereka di tengah masyarakat. Bayangan pengaruh negatip dari media komunikasi senantiasa mengganggu kenyamanan batin anggota KMK St. Martinus. Di Tengah terpaan bayangan pengaruh negatip demikian, terlahirlah sebuah kesadaran baru anggota KMK St. Martinus untuk menyususun langkah-langkah strategis dan antisipatip dalam menepis pengaruh negatip media komunikasi yang mencemaskan itu. Kesadaran baru ini mengerakan Para Pengurus KMK St. Martinus mengambil langkah-langkah antisipatip dalam meminimalisir pengaruh negatip dari media komunikasi dalam sebuah rancangan program kerja tahunan. Dalam satu kebulatan suara, terikrarlah sebuah komitmen untuk melaksanakan satu kegiatan katekese dengan tujuan untuk membuka wawasan para anggota KMK St. Martinus tentang hakekat media komunikasi beserta semua dampak yang menyertainya dan bagaimana mengefektifkan penggunaan media komunikasi bagi karya Pewartaan Kerajaan Allah. Rancangan kegiatan ini mendapat respons yang positip dari Pengurus Inti Organisasi KMK St. Martinus dan pihak Dewan Pastoral Paroki Persiapan St. Marinus Pu'urere.

Dalam rangka menyukseskan kegiatan dimaksud, Pengurus Inti KMK St. Martinus melakukan koordinasi awal dengan pihak Dewan Pastoral Paroki Persiapan St. Marinus Pu'urere untuk mendapat pertimbangan dan penguatan. Melalui pertimbangan matang, akhirnya diputuskan agar kegiatan katekese tetap dilakukan dengan menunjuk salah satu Dosen Pengampuh Mata Kuliah Pendidikan Agama Katolik Universitas Flores sebagai fasilitator Kegiatan Katekese di maksud. Tuntutan proses adminitrasi untuk kelancaran kegiatan ini pun mulai di penuhi secara perlahan-lahan oleh Pengurus Inti KMK St. Martinus dengan cara mengirim Surat Permohonan ke pihak Fakultas Keguruan dan Ilmu Pendidikan-Universitas Flores agar mengijinkan salah satu dosen Pengampuh Mata Kuliah Pendidikan Agama Katolik yang sudah di sepakati sebagai fasilitator kegiatan katekese. Setelah mendapat Surat Tugas dari pimpinan Fakultas Keguruan dan Ilmu Pendidikan, langkah pertama yang dilakukan adalah memilih dan memutuskan anggota Tim Fasilitator Katekese. Pembentukan Tim Fasilitator Katekese ini bertujuan untuk mengkoordinir dan melakukan aneka persiapan yang perlu dan urgen untuk menyukseskan kegiatan ini. Kegiatan pertama yang dilakukan oleh Tim Fasilitator Katekese adalah melakukan observasi terhadap kelompok sasar. Sasaran observasi ini adalah untuk mengetahui pemahaman dasar peserta Katekese tentang nilai-nilai Kerajaan Allah yang pernah di wartakan melalui media komunikasi. Hasil observasi terhadap kelompok sasar tersebut dianalisis dan dibahas dalam pertemuan internal Tim Fasilitator Katekese. Kristalisasi dari pembahaan ini, melahirkan sebuah tema kegiatan yang disepakati bersama, yakni: Menghayati Nilai Kerajaan Allah Dalam Era Digital Bagi Anggota KMK. St. Martinus Paroki Persiapan St. Marinus Pu'urere.

Bersamaan dengan proses observasi terhadap kelompok sasar, Tim Fasilitator Katekese berupaya memenuhi beberapa tuntutan administrasi surat menyurat dengan kelompok mitra. Setelah mendapat izin resmi dari kelompok mitra, Tim Fasilitator Katekese memantapkan lagi beberapa persiapan yang perlu, yakni: pemantapan tempat kegiatan, pemantapan alat dan sarana pendukung kegiatan (laptop, LCD, dan soundystem) dan pemantapan fungsi dan peran anggota Tim Fasilitator Katekese. Semua proses ini tetap dalam pengawasan dosen Pengampuh Mata Kuliah Pendidikan Agama Katolik. Dalam rangka menyukseskan kegiatan ini, Pihak Dewan Paroki Persiapan St. Marinus Pu'urere memperbolehkan Tim Fasilitator Kegiatan Katekese menggunakan semua fasilitas yang ada di aula pertemuan. Seluruh biaya dari kegiatan ini sepenuhnya di tanggung oleh swadaya murni anggota KMK St. Martinus dan dukungan sumbangan Paroki Persiapan St. Marinus Pu'urere. Setelah meyakini dan memastikan bahwa semua persiapan sudah matang, kegiatan ini pun akhirnya dapat dilaksanakan selama dua hari, yakni tanggal 14 Nopember 2020 dan 15 Nopember 2020. Dalam kegiatan ini, peserta akan di berikan beberapa materi yang relevan dan mendesak menyangkut pemahaman tentang media komunikasi secara umum, pengaruh positip dan negatip media komunikasi terhadap manusia serta kontribusi media komunikasi sebagai sarana pewartaan nilai-nilai Kerajaan Allah bagi 
dunia.

Materi katekese ini di susun dalam sebuah format katekese kontekstual berbasis media audiovisual dengan tujuan agar anggota KMK St. Martinus semakin sadar dan mengakui bahwa kehadiran media komunikasi terhadap diri dan hidup mereka merupakan sebuah keniscahyan yang tidak terbantahkan. Gambaran situasi demikian, diharapkan dapat melahirkan langkahlangkah konkret antisipatip untuk membangun pertahanan moralitas yang kuat sehingga tidak terjebak pada pengaruh-pengaruh negatif media komunikasi yang ditawarkan semakin transparan saat ini. Kesadaran diri yang kuat dan kokoh sebagai subyek media komunikasi akhirnya harus menjadi benteng andalan dalam menepis aneka serangan negatif dari media komunikasi. Menolak kehadiran dan pengaruh media komunikasi terhadap hidup mahasiswa katolik justeru akan mempertemukan mereka dalam sebuah pusara pertentangan batin yang bekepanjangan. Oleh karena itu, yang penting dan mendesak untuk segera dilakukan adalah menerima kehadiran media komunikasi itu sendiri berupaya membangun pertahanan moralitas yang kuat sehingga mahasiswa katolik tidak terjebak pada pengaruh-pengaruh negatif media komunikasi.

\section{METODE PELAKSANAAN}

Kegiatan Katekese ini dilaksanakan dalam panduan metode amos berbasis media audio visual. Metode amos adalah sebuah metode kontekstual yang membantu umat Allah membaca kitab suci dengan beranjak dari realitas hidup di mana mereka sekarang berada, lalu membiarkan Firman Allah menerangi realitas ini. Dalam metode ini, umat Allah diajak untuk membaca dan memahami Firman Allah dengan bertolak dari situasi konkret dan masalahmasalah sosial yang mereka alami. Situasi konkret dan masalah-masalah sosial itu dianalisis dan dibedah dengan bantuan analisis sosial dengan maksud untuk menemukan akar terdalam dari pelabagai masalah kemasyarakatan itu dan membiarkan Firman Allah dalam Kitab Suci untuk menerangi, memberikan ilham, daya dorong, kritik yang pedas dan tajam serta menemukan semangat atau spirit berjuang untuk mengatasi persoalan kemasyarakatan itu. Penggunaan metode katekese amos secara umumnya bertujuan untuk menyadarkan jemaat-jemaat Kristiani dan membantu mereka untuk melakukan sesuatu terhadap masalah yang membuat mereka menderita. Jadi, metode ini memberikan suatu cara untuk menghadapi masalah-masalah sosial dan ekonomi, membuat analisis terhadap masalah-masalah itu dalam terang Injil dan melakukan sesuatu untuk mengatasinya (Habur, 2020).

Dalam konteks Kegiatan Katekese ini, penggunaan metode amos bertujuan membuka kesadaran nurani anggota KMK St. Martinus tentang sederetan aneka persoalan pelik dan rumit yang mengancam kehidupan mahasiswa katolik sebagai akibat pengunaan media komunkasi yang kurang bertanggung jawab. Berdasarkan kesadaran tentang situasi demikian, peserta kegiatan diajak aktif dalam membangun refleksi yang mendalam untuk menemukan apa yang menjadi akar permasalahan dari semuanya. Untaian-untaian akar permasalahan yang ditemukan tersebut lalu dihidangkan di dihadapan Firman Allah untuk menemukan apa kata Firman Allah tentang permasalahan tersebut. Berdasarkan inspirasi Firman Allah atas akar permasalahan tersebut, di buatlah sebuah aksi nyata sebagai bentuk tanggapan atas Firman Allah yang di jumpai dalam proses katekese tersebut. Kegiatan katekese ini dilaksanakan dalam empat tahap. Tisera (2002) menjelaskan tahapan-tahapan katekese berbasis metode amos sebagai berikut:

Pertama, melihat situasi hidup. Dalam langkah pertama ini, fasilitator mengajak peserta untuk melihat dan menemukan masalah-masalah riil yang berhubungan dengan penggunaan media komunikasi. Untuk membantu peserta dalam melihat masalah-masalah tersebut, kepada mereka di tontonkan sebuah video yang berisikan kisah-kisah riil hidup seseorang yang menjadi korban dari media komunikasi. Video ini berperan sebagai sumber inspirasi bagi peserta untuk menemukan dan mengangkat masalah-masalah riil yangg terjadi berkaitan dengan penyalahgunaan media komunkasi. Komunikasi dan dialog antara fasilitator dan peserta 
diupayakan semakin hidup dan dialogis demi terlahirlah sharing-sharing kehidupan tentang efek penyalagunaan media komunikasi.

Kedua, menggali akar permasalahan. Langkah ini merupakan kelanjutan dari langkah pertama. Berdasarkan hidangan permasalahan yang diperoleh pada langkah pertama, pada langkah kedua ini, fasilitator secara perlahan-lahan menuntun dan memfasilitasi peserta dalam suasana yang menyenangkan sehingga mampu menemukan pelbagai kemungkinan akar permasalahannya dari masalah yang telah ditemukan. Aneka tawaran akar permasalahan tersebut harus didiskusikan secara bersama dalam kelompok untuk menemukan satu akar persoalan. Akar persoalan utama ini diyakini bersama sebagai penyebab utama munculnya aneka persoalan yang berhubungan penyalahgunaan media sosial.

Ketiga, mendengarkan Firman Allah. Berpijak pada akar permasalahan utama yang sudah di dapat; fasilitator mengajak peserta untuk dengan penuh iman mendengarkan Firman Allah yang sudah disiapkan. Langkah ini memberikan ruang dan kesempatan Firman Allah untuk menerangi masalah itu atau memberi inspirasi untuk mencari jalan keluar pemecahannya. Secara konkretnya, setelah membaca Kitab Suci, fasilitator melemparkan beberapa pertanyaan penelusuran dan pemahaman terhadap Kitab Suci, antara lain: peserta membaca dan menemukan ayat mana yang paling berkesan, apakah terdapat keterkaitan antara amanat Kitab Suci dengan akar masalah yang dijumpai, manakan penilaian Kitab Suci terhadap masalah tersebut dan bagaimana sikap dan niat saya atas penilaian Firman Allah tersebut.

Keempat, menanggapi situasi dalam terang Firman Allah. Pada langkah ini, fasilitator diminta untuk membuat kesimpulan. Alur kesimpulannya di susun dalam skema kronologis yang sistematik, yakni menggambarkan sekilas tentang isi ringkas video yang ditayangkan dan menghubungkannya dengan situasi konkret yang telah di sharingkan selama proses katekese. Selanjutnya, fasilitator menjelaskan makna Firman Allah dalam menjawabi masalah yang di jumpai. Puncak kegiatan ini, fasilitator memberikan kesimpulan yang harus melahirkan sebuah Rencana Tindak Lanjut (RTL) yang harus diwujudkan secara bersama-sama atau secara pribadi.

\section{HASIL DAN PEMBAHASAN}

Proses pelaksanaan katekese ini diikuti dengan sangat antusias oleh semua peserta. Hai ini ditunjukan dengan semangat mereka dalam menjawab pertanyaan yang diajukan fasilitator serta bersedia membagikan pengalaman pribadi dalam sharing. Di akhir kegiatan ini, para peserta dan Pengurus KMK St. Martinus diberikan kesempatan untuk mengisi angket tingkat kepuasan atas kegiatan ini sebagai bahan penilaian untuk kegiatan kedepannya. Setelah diolah hasilnya dapat di tampilkan dalam Tabel 1 berikut ini:

Tabel 1. Tingkat Kepuasan Para Peserta Terhadap Kegiatan Katekese

\begin{tabular}{clccc}
\hline Jumlah Peserta & \multicolumn{1}{c}{ Rentang Kepuasan } & F & Persentase & Total \\
\hline \multirow{3}{*}{50} & Sangat Memuaskan & 40 & $80 \%$ & \\
& Memuaskan & 6 & $12 \%$ & \multirow{2}{*}{$100 \%$} \\
& Agak Memuaskan & 4 & $08 \%$ & \\
& Kurang Memuaskan & 0 & $00 \%$ & \\
\hline
\end{tabular}

Berdasarkan data-data pada tabel 1 di ketahui bahwa dari 50 peserta kegiatan terdapat 40 peserta atau $80 \%$ yang menyatakan sangat memuaskan. Ada 6 peserta atau $12 \%$ yang menyatakan memuaskan. Terdapat 4 peserta atau $08 \%$ yang menyatakan agak memuaskan. Berdasarkan data-data ini dapat di simpulkan bahwa materi katekese dan metode katekese yang di gunakan memuaskan para Pengurus KMK St. Martinus (7 orang). Berikut ini tampilan hasil rekapan data tentang tingkat kepuasan Pengurus KMK St. Martinus Ende, yakni: 
Tabel 2. Tingkat Kepuasan Pengurus KMK St. Martinus Terhadap Kegiatan Katekese

\begin{tabular}{clccc}
\hline Jumlah Pengurus & \multicolumn{1}{c}{ Rentang Kepuasan } & F & Persentase & Total \\
\hline \multirow{2}{*}{7} & Sangat Memuaskan & 5 & $71,42 \%$ & \\
& Memuaskan & 1 & $14,28 \%$ & $100 \%$ \\
& Agak Memuaskan & 1 & $14,28 \%$ & \\
\hline
\end{tabular}

Berdasarkan data-data pada tabel dua (2) di ketahui bahwa dari tujuh (7) Pengurus KMK St. Martinus yang mengikuti dan menyaksikan kegiatan dimaksud, terdapat 5 peserta atau $71,42 \%$ yang menyatakan sangat memuaskan. Ada 1 peserta atau 14,28\% yang menyatakan memuaskan. Terdapat 1 peserta atau 14,28 \% yang menyatakan agak memuaskan dan tidak di jumpai Pengurus KMK St. Martinus yang mengatakan kurang memuaskan. Data ini secara gamblang menjelaskan bahwa semua materi dan metode kegiatan katekese telah dijalankan dengan baik sehingga peserta mampu memahami secara baik dan benar tentang apa itu nilai-nilai Kerajaan Allah serta bersedia untuk mewartakannya kepada orang lain melalui media komunikasi. Berikut ini akan di tampilkan rekapan data tentang permahaman peserta terhadap konsep nilai-nilai Kerajaan Allah yang di perjuangkan, yakni:

Tabel 3. Pemahaman Peserta Tentang Nilai-Nilai Kerajaan Allah

\begin{tabular}{|c|c|c|c|c|}
\hline \multirow{2}{*}{$\begin{array}{l}\text { Nilai Kerajaan } \\
\text { Allah } \\
\end{array}$} & \multirow{2}{*}{ Indikator } & \multirow[b]{2}{*}{$\mathrm{F}$} & \multicolumn{2}{|c|}{ Prosentase } \\
\hline & & & Item & Rata-Rata \\
\hline \multirow{4}{*}{ Keadilan } & Hubungan Adil Manusia Dengan Allah & 31 & $62 \%$ & \multirow{4}{*}{$65,5 \%$} \\
\hline & Hubungan Adil Manusia Dengan Sesama & 30 & $60 \%$ & \\
\hline & Hubungan Adil Manusia Dengan Diri Sendiri & 35 & $70 \%$ & \\
\hline & Hubungan Adil Manusia Dengan Lingkungan & 35 & $70 \%$ & \\
\hline \multirow{4}{*}{ Perdamaian } & Hubungan Baik Dengan Allah Atau Kristus & 38 & $76 \%$ & \multirow{4}{*}{$75 \%$} \\
\hline & $\begin{array}{l}\text { Hubungan Baik Dengan Sesama } \\
\text { (Damai dan Aman Dengan Sesama) }\end{array}$ & 40 & $80 \%$ & \\
\hline & $\begin{array}{l}\text { Hubungan Baik Dengan Diri Sendiri (Aman dan } \\
\text { Tenteram Batin) }\end{array}$ & 40 & $80 \%$ & \\
\hline & Hubungan Baik Dengan Lingkungan & 32 & $64 \%$ & \\
\hline \multirow{3}{*}{ Sukacita } & Menghormati Hak-Hak Asasi Orang Lain & 45 & $90 \%$ & \multirow{3}{*}{$71.3 \%$} \\
\hline & $\begin{array}{l}\text { Memberi Ruang Kepada Orang Lain Untuk } \\
\text { Berkreasi }\end{array}$ & 32 & $64 \%$ & \\
\hline & $\begin{array}{l}\text { Memberi Ruang Kepada Orang Lain Untuk } \\
\text { Berkembang }\end{array}$ & 30 & $60 \%$ & \\
\hline \multirow{3}{*}{$\begin{array}{l}\text { Dalam } \\
\text { Kudus }\end{array}$} & Kehadiran Manusia Yang Menyelamatkan & 25 & $50 \%$ & \multirow{3}{*}{$64 \%$} \\
\hline & $\begin{array}{l}\text { Kehadiran Dunia Baru: Penderitaan Di Hapus; } \\
\text { Hilangnya Hubungan Tuan-Budak; Orang Sakit } \\
\text { disembuhkan }\end{array}$ & 36 & $72 \%$ & \\
\hline & $\begin{array}{l}\text { Hubungan Baru Yang Membawa Metanoia Atau } \\
\text { Pertobatan }\end{array}$ & 35 & $70 \%$ & \\
\hline
\end{tabular}

Sumber, Fuellenbach, 2006: 221-241

Nilai-nilai Kerajaan Allah yang diangkat dalam angket ini adalah nilai keadilan, nilai perdamaian, nilai sukacita, dan nilai dalam Rohkudus. Selama 2 (dua) hari kegiatan katekese, tingkat pemahaman peserta tentang nilai-nilai Kerajaan Allah sudah mulai menunjukkan perkembangan yang berarti. Hal ini dapat di baca dalam tabel 3 berikut ini: nilai keadilan mencapai 65,5\%; nilai perdamaian mencapai 75\%, nilai sukacita mencapai $71.3 \%$, dan nilai dalam Rohkudus mencapai 64\%. Berdasarkan tabel di atas, dapat ditegaskan bahwa kegiatan katekese ini mampu membuka wawasan dan pemahaman peserta tentang nilai-nilai Kerajaan Allah. 

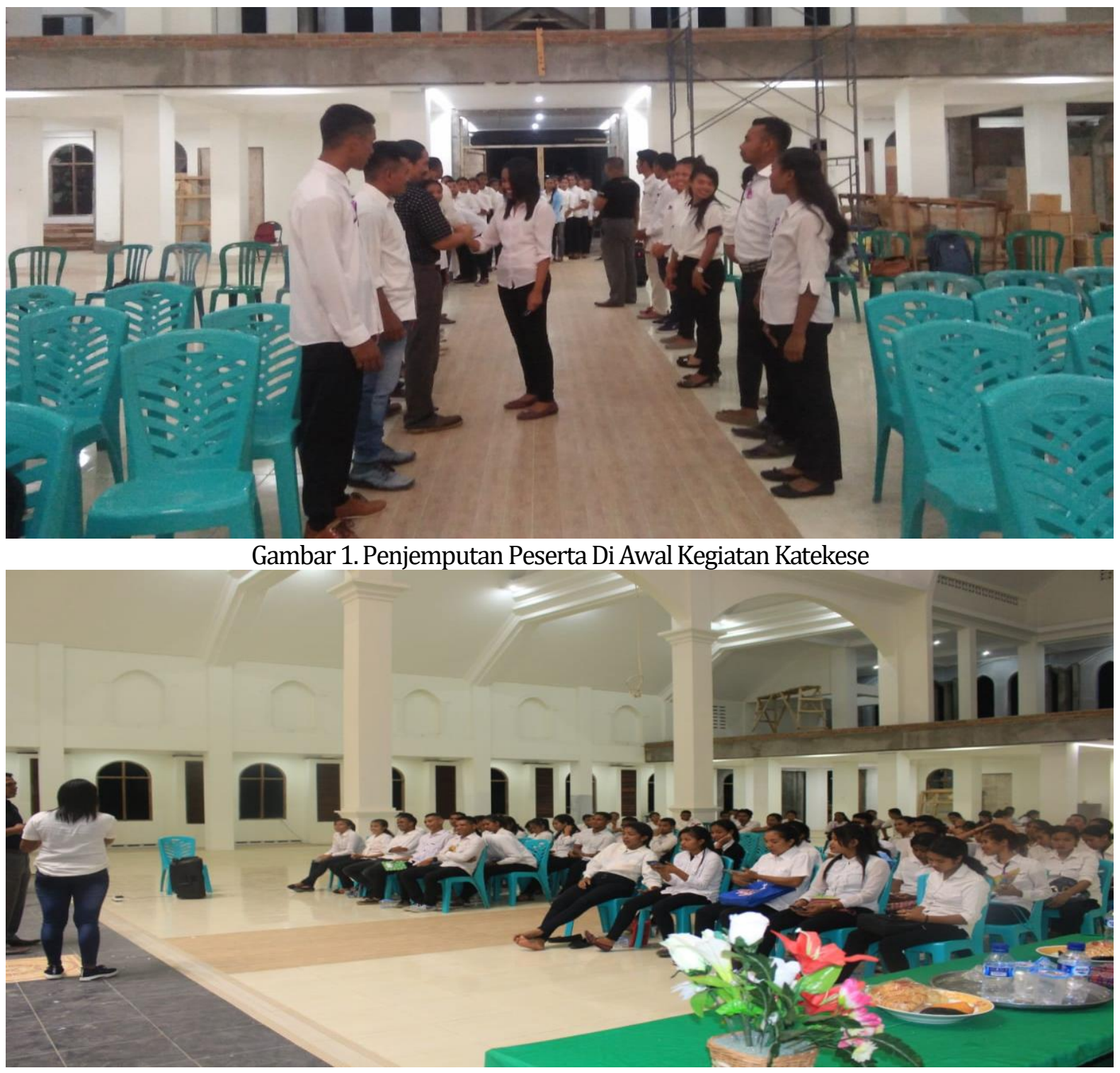

Gambar 2. Fasilitator Sedang Membawakan Materi Katekese

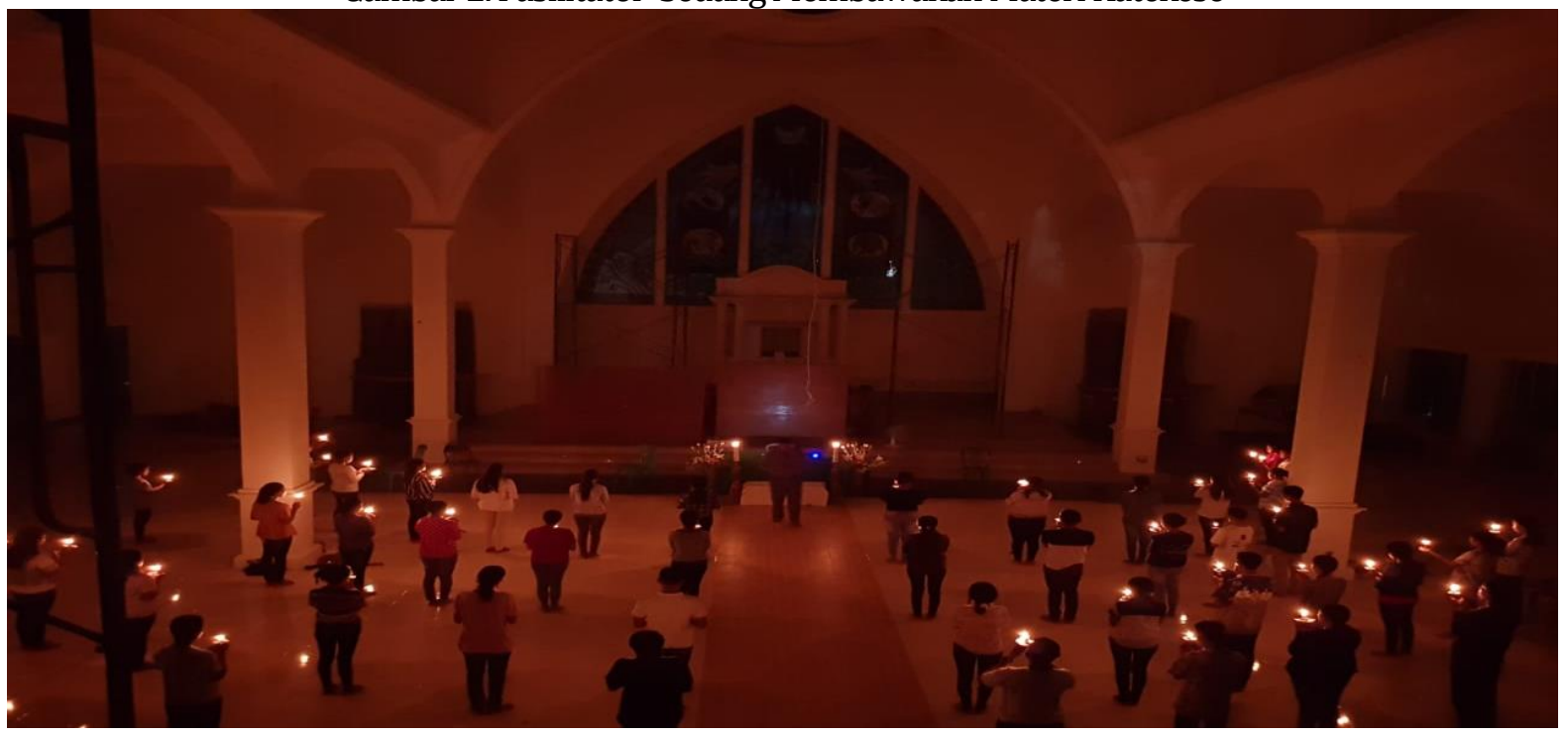

Gambar 3. Malam Renungan Bersama 


\section{SIMPULAN DAN TINDAK LANJUT}

Tema Kerajaan Allah merupakan sebuah tema sentral karya pewartaan Yesus. Kerajan Allah berarti kehadiran dan kegiatan Allah menyelamatkan di dunia lewat pribadi dan karya Yesus. Kerajaan Allah yang di wartakan dan di perjuangkan Yesus Kristus berasal dari atas, dari Allah sendiri, bukan dari manusia. Kerajaan Allah itu merupakan hadiah dari Allah yang harus diterima dengan hati seorang anak. Kerajaan Allah juga dimaksudkan sebagai sebuah transformasi struktur-struktur manusia yang menindas. Di sini Kerajaan Allah di pahami sebagai sebuah perjuangan dan penegakkan nilai-nilai injili yang selama ini sering di abaikan oleh manusia. Nilai-nilai Kerajaan Allah secara biblis di tegaskan oleh Paulus (Rm 14:17) dalam empat konsep nilai yang diperjuangkan yakni kebenaran, damai, sejahtera dan sukacita. (Fuellenbach, 2006)

Mahasiswa Katolik yang tergabung dalam wadah KMK St. Martinus Ende sebagai orangorang terbabtis telah dipanggil oleh Allah untuk terlibat dalam perjuangan dan penegakan nilainilai Kerajaan Allah dalam praksis hidup mereka. Pangilan Allah ini harus dijawab secara radikal dengan berlandaskan pada Sabda Allah demi sebuah pertobatan total sebagai ekspresi iman pada Yesus dan injil-Nya (Darmawijaya, 2000). Kegiatan katekese yang dilakukan ini, justeru dalam kerangka penyadaran dan penguatan kembali nilai-nilai Kerajaan Allah di dalam hati dan nurani mereka sekaligus berisikan ajakan pastoral agar mulai merasa terpanggil untuk mewartakan dan menghidupi nilai-nilai Kerajaan Allah itu dalam praktek hidup di tengah masyarakat.

Sedemikian penting dan mendesaknya kegiatan ini, maka dianjurkan agar ke depannya, terus dalam kerja sama dengan paroki-paroki demi penginternalisasian nilai-nilai Kerajaan Allah dalam diri dan hidup mahasiswa katolik sehingga tercipta dan terlahirlah mahasiswa Katolik dengan kualitas iman yang militan dan teruji meski berada dalam terpaan badai dan taufan perkembangan Ilmu Pengetahuan dan Teknologi yang menawarkan aneka tontonan yang menggiurkan dan sensasional. Kualitas-kualitas iman demikian jikalau di rawat dengan baik dalam lindungan, bimbingan dan kepasrahan total pada Allah akan melahirkan generasi masa depan Gereja yang tidak hanya mampu berbicara tentang nilai-nilai Kerajaan Allah tetapi sungguh-sunguh menghidupinya dalam sebuah pertobatan total yang berlandaskan pada nasehat injil.

\section{DAFTAR PUSTAKA}

Fuellenbach, John, 2006. Kerajaan Allah: Pesan Inti Ajaran Yesus Bagi Dunia Modern. Ende: Nusa Indah.

Habur, A. M., (2018). Pendekatan Holistik dalam Katekese Kontekstual Gereja Lokal Manggarai. Gereja Pewarta, 68.

Habur, A. M., (2020). Diakonia Jantung Katekese. Diakonia Gereja, 113.

Hartanti, L. E. P. (2018). Komunikasi Orang Muda di Sosial Media sebagai Influencer. WACANA: Jurnal Ilmiah Ilmu Komunikasi, 17(2), 152-162.

Iswarahadi, Y. I. (2018). Inter Mirifica: Dalam Semangat Konsili Vatikan II Memahami dan Mengintegrasikan Media Komunikasi Sosial dalam Karya Pastoral Gereja.Jurnal Orientasi

Konsili Vatikan II., (1993). Dokumen Konsili Vatikan II. R. Hardawiryana, Penerjemah). Jakarta: Obor.(Dokumen asli diterbitkan tahun 1966).

Setiawan, D. (2018). Dampak Perkembangan Teknologi Informasi Dan Komunikasi Terhadap Budaya. Jurnal Simbolika: Research and Learning in Communication Study, 4.

Setiyono, S. D., \& Supriyadi, A.. (2018). Katekese Kontekstual: Sarana Dalam Membangun Gereja Sebagaı Umat Allah Dı Parokı St. Hılarıus Klepu.JPAK: Jurnal Pendidikan Agama Katolik, 20(10), 42-56. 
St. Darmawijaya, (2000). Tritunggal Yang Mahakudus. Yogyakarta: Kanisius.

Subu, Y. Y. (2014). Media Komunikasi Dalam Terang Dekrit Inter Mirifica. Jurnal Masalah Pastoral, 3(1), 14-14.

Sudi, M. (2018). Implikasi Perkembangan Teknologi Komunikasi Terhadap Peradaban Dan Komunikasi Manusia. Gema Kampus IISIP YAPIS Biak, 13.

Tisera, Guido, (2002). Sharing Kitab Suci. Maumere: LPBAJ.

Tisera, Guido, (2001). Seperti Apakah Kerajaan Allah Itu. Jakarta: Obor. 